\title{
Efek Antioksidatif dan Akseptabilitas Bakso Daging Ayam Ras dengan Penambahan Gel Lidah Buaya
}

\author{
Antioxidative Effect and the Acceptability of Chiken Meatball Added with Aloe vera Gel \\ Chatarina Wariyah ${ }^{1 *}$, Riyanto ${ }^{2}$ \\ ${ }^{1}$ Program Studi Teknologi Hasil Pertanian, Fakultas Agroindustri, Universitas Mercu Buana \\ Yogyakarta, Jl. Wates Km 10, Yogyakarta 55753, Indonesia \\ 2Program Studi Agroteknologi, Fakultas Agroindustri, Universitas Mercu Buana Yogyakarta, \\ Jl. Wates Km 10, Yogyakarta 55753, Indonesia \\ *Email: wariyah@mercubuana-yogya.ac.id
}

Tanggal submisi: 31 Desember 2017; Tanggal penerimaan: 31 Mei 2018

\begin{abstract}
ABSTRAK
Saat ini konsumsi daging ayam ras pedaging meningkat hingga mencapai 3,7510 kg/kap/tahun. Hal ini disebabkan antara lain oleh meningkatnya jumlah penduduk dan usaha di sektor pangan yang menggunakan daging ayam ras. Disisi lain, daging ayam ras mengandung lemak cukup tinggi, sehingga mudah teroksidasi menghasilkan radikal bebas dan penurunan flavor. Daging ayam ras banyak digunakan sebagai bakso yang diolah melalui proses penggilingan daging dan perebusan, sehingga dapat memicu terjadinya oksidasi lemak. Oleh sebab itu, diperlukan antioksidan untuk menghambat oksidasi. Aloe vera diketahui mengandung senyawa flavonoid yang dapat menangkal radikal bebas. Tujuan penelitian ini adalah melakukan optimasi penambahan gel lidah buaya pada pembuatan bakso daging ayam ras untuk menghasilkan bakso dengan efek antioksidatif tinggi dan disukai. Pada penelitian ini gel lidah buaya ditambahkan untuk mensubtitusi es batu yang digunakan pada pembuatan bakso, mengingat kandungan air gel tinggi (> 98\%). Pembuatan bakso untuk setiap $250 \mathrm{~g}$ daging ayam ditambah $125 \mathrm{~g}$ tapioka, bumbu (garam, merica, bubuk bawang putih) dan es batu yang dibuat dengan variasi rasio air/gel lidah buaya (g/g): 100/0; 85/15; 70/30; 55/45 dan 40/60. Bahan dicampur menjadi adonan dan dibuat bola-bakso, selanjutnya direbus pada suhu $90{ }^{\circ} \mathrm{C}$ selama 10 menit. Analisis yang dilakukan adalah kadar air, kemampuan menangkap radikal DPPH, angka asam, peroksida dan TBA (thyobarbituric acid); sifat fisik: water holding capacity (WHC), cooking loss, tekstur (kelunakan, kekenyalan dan deformasi) dan akseptabilitas bakso ditentukan secara inderawi dengan Hedonic Test. Hasil penelitian menunjukkan bahwa bakso dengan akseptabilitas dan aktivitas antioksidasi tinggi dibuat dengan es batu dengan rasio air/gel lidah buaya $55 / 45-40 / 60(\mathrm{~g} / \mathrm{g})$. Bakso tersebut lebih lunak dan kekenyalannya disukai. Persentase WHC dan cooking loss tidak berbeda nyata, nilai RSA tinggi, sedangkan angka asam, peroksida dan TBA paling rendah.
\end{abstract}

Kata kunci: Bakso, Aloe vera; antioksidan; akseptabilitas

\section{ABSTRACT}

Currently, the consumption of broiler-chicken meat increases up to $3.7510 \mathrm{~kg} / \mathrm{cap} / \mathrm{year}$. This condition is due to the increasing of population growth and food businesses which use chicken meat. On the other hand, the chicken meat contains of high fat, thus easily oxidized and resulted in free radicals and off- flavor. Chicken meat is widely used as meatball that is processed through the stage of meat-milling and boiling which triggers fat oxidation. Therefore, an antioxidant is needed to inhibit oxidation. Aloevera contains flavonoid compounds that could scavange free radicals. The objective of this research was to optimize the addition of aloe vera gel in the chicken meatball to obtain high antioxidant effect and acceptable product. Considering its high water content ( $>98 \%)$, in this study aloe vera gel was added as an ice-substitution in the making of meatball. The meatballs were made by mixing of $250 \mathrm{~g}$ chicken meat with $125 \mathrm{~g}$ tapioca for each sample, seasoning (salt, pepper, garlic), and added ice with water/aloe vera gel ratio $(\mathrm{g} / \mathrm{g})$ of $100 / 0 ; 85 / 15 ; 70 / 30 ; 55 / 45$ and $40 / 60$. The doughs were molded in ball-shape then boiled at $90{ }^{\circ} \mathrm{C}$ for 10 minutes. The meatballs were subjected to analysis of moisture content, the ability to scavenge of 2,2-diphenyl-1picrylhydrazyl (DPPH) radical or radical scavenging activity (RSA), acid, peroxide and thyobarbituric acid (TBA) number, physical properties including water holding capacity (WHC), cooking loss, and texture (softness, chewiness and deformation) as well as acceptability by hedonic test. The results showed that the highest acceptability and antioxidative activity of meatballs was obtained in meatball with the ratio of water/gel between $55 / 45-40 / 60(\mathrm{~g} / \mathrm{g})$. 
This aforementioned meatball had softer texture and likely chewiness. The percentage of the WHC and cooking loss were not significantly different, but it had high RSA and lowest value of acid, peroxide and TBA numbers.

Keywords: Acceptability; aloe vera; antioxidant; meatball

\section{PENDAHULUAN}

Saat ini konsumsi daging unggas utamanya daging ayam ras semakin meningkat seiring dengan pertambahan jumlah penduduk, tingkat pendapatan, kesadaran pemenuhan gizi oleh masyarakat dan usaha sektor pangan. Konsumsi daging ayam ras pedaging mencapai yaitu $3,7510 \mathrm{~kg} / \mathrm{kap} /$ tahun, sedang ayam buras 0,5275 kg/kap/tahun (Nuryati dkk., 2015). Menurut Data Statistik Peternakan dan Kesehatan Hewan Tahun 2015, dalam 5 tahun terakhir peningkatan konsumsi daging ayam ras sekitar $27,13 \%$ dengan pertumbuhan rata-rata $6,05 \% / t a h u n$. Salah satu usaha sektor pangan yang menggunakan daging ayam ras sebagai bahan baku adalah pembuatan bakso. Hasil penelitian (Winang, 2015) di penggilingan daging atau tempat pembuatan adonan bakso menunjukkan bahwa sebagian bakso dibuat dengan menggunakan daging ayam ras. Padahal daging ayam ras mengandung lemak cukup tinggi yaitu sekitar $5,21 \%$ (bb) (Bostami dkk., 2017). Asam lemak penyusun trigliserida ayam ras sebagian besar adalah asam lemak tidak jenuh yaitu sebanyak $58,23-63,86 \%$ dan dari jumlah tersebut sekitar $35,20 \%$ merupakan poly-unsaturated fatty acid (PUFA) seperti asam alfa-linolenat (ALA), asam arakidonat, asam dokosapentaenoat (DPA) dan asam adrenat (Chung \& Choi, 2016). Asam lemak tersebut sangat mudah mengalami oksidasi yang dapat mengakibatkan kerusakan oksidatif dan menurunkan nilai gizi, timbulnya off-flavor (rasa, bau rancid), dan zat yang bersifat toksik. Can \& Harun (2015) menyatakan bahwa penyimpanan bakso ayam pada suhu $10^{\circ} \mathrm{C}$ selama 7 hari

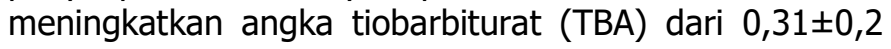
$\mathrm{mg} \mathrm{MDA} / \mathrm{kg}$ menjadi $0,63 \pm 0,21 \mathrm{mg} \mathrm{MDA} / \mathrm{kg}$ yang berarti telah terjadi oksidasi lemak selama pengolahan maupun penyimpanan. Oleh sebab itu, penting dilakukan penambahan antioksidan pada pembuatan bakso untuk menghambat peroksidasi lemak.

Lidah buaya atau aloe vera diketahui mengandung senyawa flavonoid yaitu quercetin, mericetin dan kaempferol yang dapat menangkap radikal bebas (Sultana \& Anwar, 2008). Hasil oksidasi asam lemak berupa radikal bebas berbentuk reactive oxygen spesies (ROS) (Tao, 2015) seperti radikal alkoxi dan radikal peroksida (Cheng, 2016). Aktivitas antioksidasi daun lidah buaya cukup tinggi walaupun telah diekstrak dan atau diolah menjadi bubuk instan (Wariyah \& Riyanto, 2016), namun dalam bentuk gel segar aktivitas antioksidasinya paling tinggi. Aktivitas antioksidasi gel lidah buaya yang dinyatakan dalam persentase radical scavenging activity (RSA) sebesar $35,17 \%$ dan kemampuan menghambat peroksidasi lemak 49,53\% (Riyanto \& Wariyah, 2012). Oleh sebab itu tujuan penelitian ini adalah mengembangkan penggunaan gel lidah buaya ke dalam pangan berlemak seperti bakso daging ayam ras, agar diperoleh bakso yang disukai dan dengan aktivitas antioksidasi tinggi serta aman.

\section{METODE PENELITIAN}

\section{Bahan}

Bahan utama yang digunakan untuk pembuatan bakso adalah daging ayam ras (broiler) yang dibeli dari pasar tradisional di Yogyakarta, daun lidah buaya (Aloe vera var. chinensis) diperoleh dari pasar swalayan Superindo serta tapioka (merk Rose Brand), merica bubuk (merk Ladaku), garam (merk Refina) dibeli dari Toko Intisari di Yogyakarta.

Bahan kimia yang digunakan dengan kualifikasi pro analysis meliputi: bahan kimia untuk analisis bilangan asam adalah $\mathrm{KOH}$ 85\% (Merck, Darmstadt, Jerman), indikator phenolphthalein $\mathrm{C}_{20} \mathrm{H}_{4} \mathrm{OH} 1 \%$ (Merck, Darmstadt, Jerman), ethanol 100\% (Merck, Darmstadt, Jerman), analisis kadar lemak menggunakan petroleum benzene $100 \%$ (Merck, Darmstadt, Jerman); angka peroksida menggunakan $\mathrm{CH}_{3} \mathrm{COOH} 100 \%$ (Merck, Darmstadt, Jerman), KI 99,5\% (Merck, Darmstadt, Jerman), $\mathrm{Na}_{2} \mathrm{~S}_{2} \mathrm{O}_{3}>97 \%$ (Merck, Darmstadt, Jerman), $\mathrm{HCl} 37 \%$ (LabChem, AS); angka TBA dengan asam tiobarbiturat $>99 \%$ (Merck, Darmstadt, Jerman); aktivitas antioksidan dengan DPPH (Sigma Aldrich, Jerman) dan ethanol $100 \%$ (Merck, Darmstadt, Jerman). Standar asam galat untuk analisis fenol dari asam gallat (Sigma Aldrich, Jerman).

\section{Alat}

Peralatan untuk pembuatan bakso adalah Food Processor (650 watt 1,5 L, Philips, Belanda), kompor (Quantum, Indonesia), alat perebus, panci dan pisau. Alat untuk analisis meliputi UV Vis Spectrophotometer (UV mini 1240, Shimadzu, Jepang), timbangan (PA214, OHAUS, AS), oven (DIN 40050 IP 20, Memmert, Jerman), sentrifus (EBA 8S, Hettich, Jerman), vortex (II TY 37600, Maxi Mix, AS), Soxhlet (E5CWL, Memmert, Jerman) dan alat-alat gelas untuk analisis kimia dari Pyrex (Iwaki, Jepang). Peralatan-peralatan tersebut berada di laboratorium Pengolahan Hasil Pertanian, Universitas Mercu Buana Yogyakarta. Alat untuk menguji tekstur (PRO LITE vl.0, LFRA, Inggris) yang digunakan berada di Laboratorium Bioteknologi, Universitas Atmajaya Yogyakarta. 


\section{Analisis pada Gel Lidah Buaya dan Daging Ayam Ras}

Daun lidah buaya dihilangkan kulit luarnya, dicuci, kemudian dipotong dan dicincang halus. Gel lidah buaya sebelum digunakan dianalisis terlebih dahulu kadar airnya dengan metode pemanasan (AOAC, 1970), total fenol dengan metode Folin-Ciocalteu (Horax dkk., 2005), analisis aktivitas antioksidan dengan DPPH (Hu dkk., 2003). DPPH Radical Scavenging Activity (RSA) yang dihitung dengan formula sesuai Persamaan 1 (Yen \& Duh, 1994).

Radical Scavenging Activity $(\%)=[1-(\mathrm{At} / \mathrm{Ao})] \times 100$

Ao adalah absorbansi sampel pada $\mathrm{t}=0$ menit, dan $A t$ adalah absorbansi sampel pada $\mathrm{t}=30$ menit (awal steady state).

Daging ayam ras diambil dari bagian dada dan paha atas kemudian dianalisis kadar airnya dengan metode pemanasan, kadar lemaknya dengan destilasi Soxhlet (AOAC, 1970), dan angka asam menggunakan metode Apriyantono dkk. (1989).

\section{Pembuatan Bakso}

Pembuatan bakso mengacu pada Melia dkk. (2010) dengan modifikasi. Bahan berupa daging ayam ras pedaging untuk tiap perlakuan sebanyak 250 gram, ditambah masing-masing tepung tapioka $125 \mathrm{~g}$, es batu $100 \mathrm{~g}$ yang dimodifikasi dengan penambahan gel lidah buaya. Gel lidah buaya digunakan untuk substitusi air (es batu) mengingat kadar air gel lidah buaya tinggi yaitu $98,68 \pm 0,03 \%$. Fungsi es batu adalah untuk menurunkan suhu ketika penggilingan, sehingga tidak merubah struktur komponen dalam adonan. Sebelum dibekukan, gel lidah buaya diiris dengan ukuran sekitar $1 \times 1 \mathrm{~cm}$. Variasi perlakuan pada penelitian ini adalah rasio jumlah air/gel lidah buaya $(\mathrm{g} / \mathrm{g})$ untuk pembuatan es batu, yaitu: 100/0; 85/15; 70/30; 55/45, dan 40/60. Bumbu-bumbu yang ditambahkan untuk setiap perlakuan sama yaitu garam, bawang putih, dan merica halus masing-masing sebanyak $10 \mathrm{~g}$. Bahan dicampur menggunakan food processor menjadi adonan, selanjutnya dibuat bola-bola ( $\pm 10 \mathrm{~g}$ ) dan direbus dalam air suhu $90^{\circ} \mathrm{C}$ selama 10 menit (sampai mengapung). Bahan untuk pembuatan bakso dengan penambahan gel lidah buaya dapat dilihat pada Tabel 1.

Tabel 1. Formula pembuatan bakso dengan penambahan gel lidah buaya

\begin{tabular}{cccccc}
\hline $\begin{array}{c}\text { Es batu dengan } \\
\text { variasi rasio } \\
\text { air/gel lidah } \\
\text { buaya }(\mathrm{g} / \mathrm{g})\end{array}$ & $\begin{array}{c}\text { Daging } \\
\text { ayam } \\
(\mathrm{g})\end{array}$ & $\begin{array}{c}\text { Tapioka } \\
(\mathrm{g})\end{array}$ & $\begin{array}{c}\text { Garam } \\
(\mathrm{g})\end{array}$ & $\begin{array}{c}\text { Bawang } \\
\text { putih } \\
(\mathrm{g})\end{array}$ & $\begin{array}{c}\text { Merica } \\
(\mathrm{g})\end{array}$ \\
\hline $100 / 0$ & 250 & 125 & 10 & 10 & 10 \\
$85 / 15$ & 250 & 125 & 10 & 10 & 10 \\
$70 / 30$ & 250 & 125 & 10 & 10 & 10 \\
$55 / 45$ & 250 & 125 & 10 & 10 & 10 \\
$40 / 60$ & 250 & 125 & 10 & 10 & 10 \\
\hline
\end{tabular}

\section{Analisis Aktivitas Antioksidasi Bakso dengan Penambahan Gel Lidah Buaya}

Sampel bakso dengan variasi penambahan gel lidah buaya dianalisis: aktivitas antioksidasi dengan DPPH $(\mathrm{Hu}$ dkk., 2003). Persentase RSA sampel dihitung sesuai formula Yen \& Duh (1994). Data pendukung aktivitas antioksidasi yang dianalisis adalah kadar air dengan metode pemanasan (AOAC, 1970), angka asam, angka peroksida, dan angka TBA (Apriyantono dkk., 1989).

\section{Pengujian Sifat Fisik Bakso dengan Penambahan Gel Lidah Buaya}

Pengujian sifat fisik sampel bakso meliputi tekstur (kelunakan, kekenyalan dan deformasi) menggunakan Texture Analyzer dan Water Holding Capacity (WHC) mengacu pada Luckose \& Pandey (2014). WHC dihitung dengan Persamaan 2.

$$
\begin{aligned}
& \text { Water Holding Capacity }(\%) \\
& =1-\mathrm{T} / \mathrm{M} \times 100=1-(\mathrm{B}-\mathrm{A}) / \mathrm{M} \times 100 \% \\
& \mathrm{~T}=\text { total cairan yang hilang selama pemasakan dan } \\
& \text { sentrifugasi }(\mathrm{g}) \\
& \mathrm{M}=\text { total air dalam sampel }(\mathrm{g}) \\
& \mathrm{B}=\text { berat sampel sebelum sentrifugasi }(\mathrm{g}) \\
& \mathrm{A}=\text { berat sampel setelah sentrifugasi }(\mathrm{g})
\end{aligned}
$$

Sedangkan cooking loss mengacu pada Ammar dkk. (2014), dihitung berdasarkan Persamaan 3.

$$
\text { Cooking Loss }(\mathrm{g} / 100 \mathrm{~g})=\text { Wr-Wc } 100 / \mathrm{Wr}
$$

$\mathrm{Wr}=$ berat sebelum dimasak (bakso mentah) ( $\mathrm{g}$ )

$\mathrm{Wc}=$ berat setelah dimasak $(\mathrm{g})$

Pemasakan dilakukan pada suhu $90^{\circ} \mathrm{C}$ selama 10 menit.

\section{Pengujian Tingkat Kesukaan Bakso}

Untuk menentukan tingkat kesukaan bakso dengan penambahan gel lidah buaya, maka dilakukan uji menggunakan metode Hedonic Test (Kramer \& Twigg, 1966). Kategori panelis yang digunakan semi terlatih, sebanyak 20 orang. Panelis diminta menilai kesukaan terhadap aroma, warna, tekstur, rasa dan kesukaan keseluruhan dengan skala nilai 1 (sangat suka) sampai dengan 7 (sangat tidak suka). Dari hasil pengujian akan diperoleh es batu dengan rasio air/gel lidah buaya yang tepat, agar diperoleh bakso dengan akseptabilitas tinggi.

\section{Rancangan Percobaan}

Rancangan percobaan yang digunakan dalam penelitian ini adalah Rancangan Acak Lengkap dengan faktor es batu dengan rasio air/gel lidah buaya. Perbedaan antar perlakuan ditentukan dengan uji $F$, selanjutnya beda nyata antar sampel ditentukan dengan Duncan's Multiples Range Test (DMRT) (Gacula dkk., 1984) yang dianalisis dengan program SPSS13,0. 


\section{HASIL DAN PEMBAHASAN}

\section{Karakteristik Bahan Baku}

Bakso dengan penambahan gel lidah buaya dibuat dari daging ayam ras memiliki karakteristik kadar lemak $3,66 \pm 0,70 \%$, air $75,55 \pm 0,35 \%$ dan angka asam $3,57 \pm 0,02 \%$. Menurut Bostami dkk. (2017), kadar lemak daging ayam ras (broiler) sekitar 5,21\%, air 73,61\% dan dinyatakan bahwa komposisi daging ayam ras dipengaruhi oleh pakan yang diberikan. Lidah buaya yang digunakan kadar airnya $98,68 \pm 0,03 \%$ dan kadar fenol

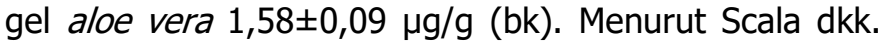
(2013), kadar air gel lidah buaya $98,93 \pm 0,06 \mathrm{~g} / 100 \mathrm{~g}$ gel segar dan total fenol dalam bubuk lidah buaya $2,64 \pm 0,105 \mu \mathrm{g} / \mathrm{g}$ (bk) (Wariyah \& Riyanto, 2016). Hu dkk. (2003) menyatakan bahwa kadar fenol gel lidah buaya dipengaruhi oleh umur tanaman, lidah buaya dengan umur tanam 3 tahun memiliki fenol tinggi.

\section{Aktivitas Antioksidasi Bakso dengan Penambahan Gel Lidah Buaya}

Bakso dengan penambahan gel lidah buaya ditentukan aktivitas antioksidasinya berdasarkan kemampuan menangkap radikal bebas DPPH. DPPH merupakan senyawa radikal berwarna ungu yang apabila radikal tersebut ditangkap oleh antioksidan, maka intensitas warna ungu berkurang ketika ditera menggunakan spektrometer pada $\lambda 517 \mathrm{~nm}$. Nilai absorbansi semakin kecil berarti aktivitas antioksidasi yang semakin tinggi. Gambar 1 menunjukkan aktivitas antioksidasi bakso gel lidah buaya dan antioksidan sintetis BHT (Butylated Hydroxyanisole). Aktivitas antioksidasi BHT lebih tinggi dibanding dengan bakso dengan gel lidah buaya.

Oksidasi lemak diawali dengan hidrolisis trigliserida menghasilkan asam lemak dan gliserol. Selanjutnya asam lemak tidak jenuh teroksidasi menghasilkan hidroperoksida, kemudian aldehid, keton dan puncaknya adalah terbentuknya malonaldehid (Tao, 2015). Oksidasi dapat dipicu adanya panas, sinar, logam dan oksigen menghasilkan ROS (Reactive Oxygen Spesies) seperti aldehid, peroksida, kolesterol oksida. Oksidasi lipid dapat berlanjut selama pemasakan. Tabel 2 menunjukkan persentase RSA, kadar air, angka asam, peroksida, dan TBA (kadar malonaldehid) pada bakso dengan penambahan gel lidah buaya.

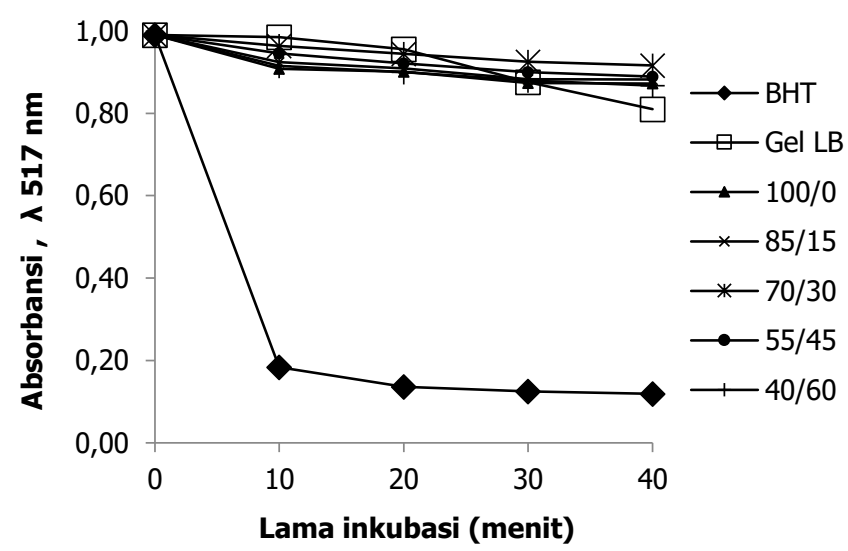

Gambar 1. Aktivitas antioksidasi bakso menangkap radikal DPPH dibandingkan dengan BHT 0,1 $\mathrm{g}$ (bk) dan gel lidah buaya segar (Gel LB), bakso dengan es batu yang dibuat dengan rasio air/gel lidah buaya 100/0, 85/15, 70/30, 55/45, dan 40/60.

\section{Radical Scavenging Activity (RSA)}

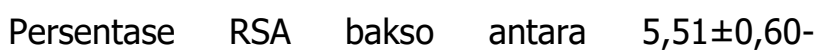
$12,89 \pm 1,87 \%$ dan sekitar $89,10 \pm 0,12 \%$ pada BHT murni. Bakso dengan penambahan gel lidah buaya memiliki aktivitas antioksidasi, meskipun lebih rendah dibandingkan dengan BHT murni. Hal ini wajar mengingat komponen utama bakso adalah daging dan tapioka.

Hasil analisis statistik RSA menunjukkan perbedaan yang nyata artinya semakin banyak penambahan gel lidah buaya, persentase RSA semakin besar. Menurut Sultana \& Anwar (2008), gel lidah buaya mengandung senyawa fenol yaitu quercetin, mericetin dan kaempferol, senyawa ini memiliki aktivitas antioksidasi menangkap radikal bebas. Riyanto \& Wariyah (2012) telah membuktikan bahwa gel dalam minuman lidah buaya mempunyai nilai RSA 7,12\%, dan pada bubuk hasil mikroenkapsulasi gel lidah buaya menggunakan maltodekstrin persentase RSA mencapai 35,59\% (Wariyah \& Riyanto, 2016). Oleh sebab itu, semakin banyak gel lidah buaya dalam bakso, maka nilai RSA semakin tinggi.

\section{Kadar air}

Air dalam bahan pangan menentukan tekstur, kenampakan dan citarasa. Menurut SNI 01-3818-1995, kadar air bakso maksimum 70\% (Anonim, 1995). Hasil

Tabel 2. Aktivitas antioksidasi bakso dengan penambahan lidah buaya

\begin{tabular}{crrrrr}
\hline $\begin{array}{c}\text { Es batu dengan rasio } \\
\text { air/gel lidah buaya }\end{array}$ & RSA (\%)** & $\begin{array}{c}\text { Kadar air }(\% \\
\text { bb)* }\end{array}$ & $\begin{array}{c}\text { Angka asam } \\
\text { mg/g** }\end{array}$ & $\begin{array}{c}\text { Angka Peroksida } \\
(\mathrm{mm} . \mathrm{g} / \mathrm{kg} \text { bahan)** }\end{array}$ & $\begin{array}{c}\text { TBA } \\
(\mathrm{MDAg} / \mathrm{kg})^{* *}\end{array}$ \\
\hline $100 / 0$ & $5,51 \pm 0,60^{\mathrm{a}}$ & $58,31 \pm 0,02$ & $3,94 \pm 0,05^{\mathrm{d}}$ & $19,39 \pm 0,10^{\mathrm{d}}$ & $0,44 \pm 0,02^{\mathrm{d}}$ \\
$85 / 15$ & $4,86 \pm 0,75^{\mathrm{a}}$ & $59,31 \pm 0,32$ & $3,22 \pm 0,02^{\mathrm{a}}$ & $20,67 \pm 0,38^{\mathrm{e}}$ & $0,30 \pm 0,01^{\mathrm{c}}$ \\
$70 / 30$ & $7,70 \pm 0,72^{\mathrm{b}}$ & $59,96 \pm 1,67$ & $3,21 \pm 0,02^{\mathrm{a}}$ & $18,20 \pm 0,10^{\mathrm{c}}$ & $0,23 \pm 0,02^{\mathrm{b}}$ \\
$55 / 45$ & $11,15 \pm 0,59^{\mathrm{c}}$ & $59,25 \pm 0,63$ & $3,32 \pm 0,03^{\mathrm{b}}$ & $11,79 \pm 0,20^{\mathrm{b}}$ & $0,17 \pm 0,02^{\mathrm{a}}$ \\
$40 / 60$ & $12,89 \pm 1,87^{\mathrm{d}}$ & $59,58 \pm 1,73$ & $3,46 \pm 0,02^{\mathrm{c}}$ & $11,30 \pm 0,10^{\mathrm{a}}$ & $0,19 \pm 0,02^{\mathrm{a}}$ \\
\hline
\end{tabular}

*Tidak berbeda nyata.

**Huruf yang sama pada kolom yang sama menunjukkan tidak berbeda nyata $(p<0,05)$. 
penelitian menunjukkan kadar air bakso dengan atau

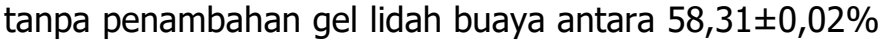

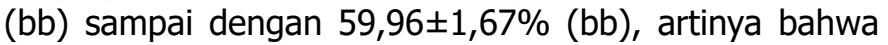
kadar yang bakso masih memenuhi persyaratan kualitas bakso. Hasil uji kadar air terhadap bakso disajikan pada Tabel 2. Dari hasil analisis statistik menunjukkan bahwa perlakuan dengan penambahan gel lidah buaya tidak memberikan pengaruh nyata pada kadar air bakso $(p<0,05)$. Hal ini disebabkan formulasi bakso yang mengacu pada Melia dkk. (2010) dengan penambahan es batu sebanyak $100 \mathrm{~g} / 250 \mathrm{~g}$ daging dan penambahan gel lidah buaya sebagai substitusi air sudah mempertimbangkan kadar air gel yaitu sebanyak 98,68 $\pm 0,03 \%$ (bb). Oleh sebab itu, kadar air bakso tidak berbeda nyata.

\section{Angka asam dan peroksida}

Hasil analisis statistik terhadap angka asam bakso (Tabel 2) menunjukkan perbedaan yang nyata. Bakso tanpa gel lidah buaya angka asamnya paling tinggi, sedangkan bakso dengan penambahan gel lidah buaya angka asamnya lebih rendah. Adawiyah dkk. (2012) menyatakan hidrolisis lemak dipengaruhi aktivitas air $\left(a_{w}\right)$, semakin tinggi $a_{w}$ hidrolisis lemak semakin besar. Pada bakso tanpa lidah buaya kemungkinan $a_{w}$ tinggi, sedangkan pada bakso dengan penambahan lidah buaya $\mathrm{a}_{\mathrm{w}}$ lebih rendah mengingat dalam gel lidah buaya terkandung senyawa seperti pektin terlarut, protein dan mineral yang mampu mengikat air (Munoz dkk., 2015). Pada bakso dengan gel lidah buaya, semakin banyak gel lidah buaya, angka asamnya semakin tinggi. Mekanisme hidrolisis dan oksidasi lemak yang diawali dengan meningkatnya asam lemak bebas selanjutnya asam lemak akan segera teroksidasi menjadi peroksida (Cheng, 2016). Bakso tanpa gel lidah buaya memiliki angka peroksida yang tinggi, hal ini menunjukkan bahwa sebagian asam lemak bebas sudah mengalami peroksidasi menghasilkan peroksida $(\mathrm{ROOH})$. Demikian pula untuk sampel dengan rasio air/gel lidah buaya 85/15. Selanjutnya, angka peroksida dalam bakso yang ditambah gel lidah buaya semakin turun. Hal ini

Tabel 3. Sifat fisik bakso dengan penambahan lidah buaya menunjukkan bahwa oksidasi asam lemak menjadi peroksida dihambat oleh gel lidah buaya. Hu dkk. (2003) menyatakan bahwa ekstrak daun lidah buaya bersifat sebagai antioksidan, karena kemampuannya menangkap radikal bebas DPPH (1,1-Diphenyl-2picrylhydrazil). Hal ini sejalan dengan penelitian sebelumnya oleh Riyanto \& Wariyah (2012) pada minuman lidah buaya yang diolah melalui pemanasan pada suhu $80^{\circ} \mathrm{C}$, dimana diperoleh nilai RSA 7,39\% dan penghambatan peroksidasi lemak sebesar $21,55 \%$. Oleh sebab itu, semakin banyak gel lidah buaya dalam bakso, pembentukan peroksida semakin rendah.

\section{Angka TBA}

Senyawa hasil autoksidasi yang mengakibatkan tengik atau rancid adalah hidroperoksida yang mengalami pemecahan menjadi aldehid dan keton, sebagai puncaknya akan terbentuk malonaldehid, dan hidroksi alkenal seperti 4-hidroksi-2nonenal (HNE) yang diturunkan dari oksidasi $\omega-6$ PUFA dan 4-hidroksi-2heksenal (HNE) produk dari perokisidasi oksidasi $\omega-3$ PUFA (Tao, 2015). Malonaldehid merupakan hasil pemecahan peroksida yang dapat diidentifikasi dengan analisis TBA. Semakin tinggi angka TBA, maka malonaldehid semakin banyak atau berarti oksidasi lemak semakin tinggi. Hasil analisis statistik menunjukkan bahwa angka TBA bakso dengan penambahan gel lidah buaya berbeda nyata. Semakin banyak gel lidah buaya, nilai TBA semakin kecil. Hal ini berkaitan dengan terbentuknya peroksida yang semakin sedikit (Tabel 1), sehingga pembentukan malonaldehid dari peroksida juga rendah. Can \& Harun (2015) menyatakan bahwa angka TBA bakso ayam broiler

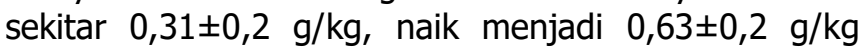
setelah disimpan selama 7 hari pada suhu $10{ }^{\circ} \mathrm{C}$. Hasil ini membuktikan bahwa gel lidah buaya mampu menghambat oksidasi lemak pada bakso ayam.

\section{Sifat Fisik Bakso dengan Penambahan Gel Lidah Buaya}

Sifat fisik bakso yang diuji adalah WHC, cooking loss, tekstur (kelunakan, kekenyalan, dan deformasi). Hasil analisis sifat fisik bakso dapat dilihat pada Tabel 3.

\begin{tabular}{cccccc}
\hline \multirow{2}{*}{$\begin{array}{c}\text { Es batu dengan } \\
\text { rasio air/gel lidah } \\
\text { buaya }\end{array}$} & WHC (\%)* & $\begin{array}{c}\text { Cooking loss } \\
(\mathrm{g} / 100 \mathrm{~g})^{*}\end{array}$ & & & \multicolumn{2}{c}{ Tekstur } \\
\cline { 4 - 6 } & & & & & \\
\hline
\end{tabular}

\footnotetext{
*Tidak berbeda nyata.
}

**Huruf yang sama pada kolom yang sama menunjukkan tidak berbeda nyata $(p<0,05)$ 


\section{Water Holding Capacity (WHC)}

Water holding capacity atau daya mengikat air adalah kemampuan daging/bakso untuk mengikat/menahan air (Huff-Lonergan \& Lonergan, 2005). Daya mengikat air merupakan hal yang penting untuk kualitas daging dan produk daging termasuk bakso. Semakin besar daya mengikat air, semakin tinggi presentase air yang terikat dalam produk. Hasil analisis statistik WHC bakso menunjukkan tidak ada perbedaan yang nyata seperti terlihat pada Tabel 3. Hal ini disebabkan komponen utama gel lidah buaya adalah air $(98,68 \pm 0,03 \%)$.

Nilai WHC bakso dengan atau tanpa penambahan lidah buaya berkisar antara $83,04-85,42 \%$. Senyawa yang dapat mengikat air dalam bakso adalah protein dan pati/tapioka. Tapioka berfungsi sebagai perekat pada pembuatan bakso yang dapat membentuk gel ketika dipanaskan. Gelatinisasi pati mengakibatkan pengikatan dan pemerangkapan air yang cukup besar (Tako dkk., 2014), yang selanjutnya ketika didinginkan akan mengalami retrogradasi. Air bersifat polar, besarnya nilai WHC juga ditentukan oleh protein dalam daging. Protein daging mengandung asam amino polar, bermuatan, sehingga mampu mengikat air (Huff-Lonergan \& Lonergan, 2005). Menurut Montolalu dkk. (2013), semakin banyak tapioka yang ditambahkan pada daging ayam broiler, nilai WHC-nya semakin besar. Bakso dengan rasio daging/tapioka sebesar $8 / 1$, nilai WHC-nya $48,82 \%$. Pada penelitian ini rasio daging/tapioka yang digunakan adalah $250 \mathrm{~g} / 125 \mathrm{~g}$ atau $2 / 1$, sehingga WHCnya lebih besar.

\section{Cooking loss}

Cooking loss dihitung berdasarkan pengurangan berat bahan (adonan) sebelum dan setelah pemanasan pada suhu $90{ }^{\circ} \mathrm{C}$ selama 10 menit. Hasil analisis cooking loss menunjukkan tidak ada perbedaan yang nyata.

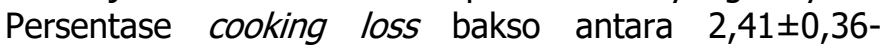
$3,82 \pm 0,23 \mathrm{~g} / 100 \mathrm{~g}$. Faktor yang menentukan cooking loss adalah jumlah daging dan tapioka sebagai binder. Hasil penelitian Swarno dkk. (2015) pada bakso daging kalkun menunjukkan semakin banyak daging yang digunakan dengan jumlah tapioka sama, cooking loss bakso semakin rendah. Nilai cooking loss yang diperoleh dalam penelitian ini adalah 5,32 $\pm 1,24-6,12 \pm 0,72 \mathrm{~g} / 100 \mathrm{~g}$. Pada penelitian ini jumlah daging dan tapioka yang digunakan sama, sehingga cooking loss tidak berbeda nyata.

\section{Tekstur bakso}

Tekstur adalah kinerja bahan bila dikenai gaya, sehingga tekstur dapat dinyatakan dalam gaya yang dapat ditahan sampai bahan mengalami kerusakan. Tekstur juga dapat dinyatakan sebagai deformasi yaitu pergeseran relatif titik atau tempat bila bahan dikenai gaya (Suyitno, 1987). Hasil pengukuran tekstur bakso dapat dilihat pada Tabel 3 yang dinyatakan sebagai kelunakan, kekenyalan dan deformasi.

\section{Kelunakan}

Kelunakan bakso dinyatakan sebagai gaya yang dapat ditahan sampai bahan mengalami kerusakan, artinya semakin kecil gaya yang dapat ditahan, tekstur bahan dalam hal ini bakso semakin lunak. Hasil analisis statistik menunjukkan bahwa kelunakan bakso dengan penambahan gel lidah buaya berbeda nyata. Kelunakan bakso dengan gel lidah buaya berkisar antara $1513,13 \pm 33,63 \mathrm{~g}$ sampai $1760,04 \pm 81,13 \mathrm{~g}$. Semakin banyak gel yang ditambahkan, bakso yang dihasilkan cenderung semakin lunak. Tabel 3 terlihat bahwa bakso tanpa gel lidah buaya paling keras, sedangkan bakso yang ditambah lidah buaya kelunakan sama. Menurut Can \& Harun (2015), kelunakan bakso ayam yang hanya ditambah bumbu dan tanpa tapioka berkisar antara $5670 \pm 190 \mathrm{~g}$. Faktor yang mempengaruhi kelunakan bakso adalah kadar air, serta komponen lain dalam gel lidah buaya. Kadar air bakso tidak berbeda nyata, sedangkan komponen lain dalam gel lidah buaya antara lain serat sebanyak $1,38 \pm 1,13 \%$ yang terdiri dari selulosa dan hemiselulosa yang sulit berasosiasi dengan protein (Munoz dkk., 2015). Komponen utama bakso adalah protein daging ayam, interaksi yang kurang dengan protein mengakibatkan strukturnya menjadi kurang mampat, sehingga bakso yang ditambah gel lidah buaya lebih lunak.

\section{Kekenyalan}

Sifat kenyal adalah sifat reologi produk pangan plastis yang bersifat deformasi. Sifat reologi adalah sifat fisik produk pangan berkaitan dengan deformasi bentuk akibat terkena gaya mekanis. Bakso semakin kenyal apabila gaya yang dibutuhkan untuk berubah bentuk semakin besar. Hasil analisis statistik menunjukkan bahwa kekenyalan bakso yang ditambah gel lidah berbeda nyata $(p<0,05)$. Menurut Can \& Harun (2015), kekenyalan bakso $5021 \pm 1,41 \mathrm{~g} / \mathrm{mm}$. Pada penelitian ini kekenyalan yang diperoleh antara $4436,97 \pm 92,52-$ $5362,98 \pm 223,06 \mathrm{~g} / \mathrm{mm}$. Semakin banyak gel lidah buaya kekenyalan bakso semakin berkurang. Menurut Montolalu dkk. (2013), kekenyalan bakso ditentukan tepung yang digunakan, dalam hal ini tapioka dan daging. Bakso akan kenyal apabila daya ikat air semakin besar. Tapioka atau pati ubikayu ketika dipanaskan akan mengalami gelatinisasi dengan kemampuan mengikat dan memerangkap air (Tako dkk., 2014), sedangkan protein otot daging merupakan senyawa polar yang mampu mengikat air dengan kuat (Huff-Lonergan \& Lonergan, 2005). Hasil penelitian ini menunjukkan WHC bakso tidak berbeda nyata, sedangkan kekenyalan bakso semakin rendah dengan semakin banyak lidah buaya. Hal ini kemungkinan disebabkan semakin banyak gel lidah buaya, semakin banyak komponen lidah buaya (selulosa, hemiselulosa) yang terikut dalam bakso. 
Tabel 4. Hasil uji kesukaan bakso dengan penambahan lidah buaya

\begin{tabular}{cccccc}
\hline $\begin{array}{c}\text { Es dengan rasio air/gel } \\
\text { lidah buaya }\end{array}$ & Aroma* & Warna** & Kekenyalan** & Rasa* & $\begin{array}{c}\text { Kesukaan* } \\
\text { keseluruhan }\end{array}$ \\
\hline $100 / 0$ & 3,55 & $3,35^{\mathrm{ab}}$ & $3,80^{\mathrm{b}}$ & 3,25 & 3,40 \\
$85 / 15$ & 3,30 & $3,55^{\mathrm{ab}}$ & $3,55^{\mathrm{ab}}$ & 3,60 & 3,55 \\
$70 / 30$ & 3,55 & $3,80^{\mathrm{b}}$ & $3,95^{\mathrm{b}}$ & 3,25 & 3,30 \\
$55 / 45$ & 3,45 & $3,10^{\mathrm{a}}$ & $3,20^{\mathrm{a}}$ & 3,65 & 3,15 \\
$40 / 60$ & 3,50 & $3,60^{\mathrm{ab}}$ & $3,20^{\mathrm{a}}$ & 3,00 & 3,25 \\
\hline
\end{tabular}

\footnotetext{
*Tidak berbeda nyata.

**Huruf yang sama pada kolom yang sama menunjukkan tidak berbeda nyata $(p<0,05)$

***angka 1: sangat disukai; 3: disukai; 7: sangat tidak disukai
}

Interaksi serat dengan air yang kurang mengakibatkan kekenyalan bakso semakin rendah.

\section{Deformasi}

Deformasi yaitu pergeseran relatif titik atau tempat bila bahan dikenai gaya (Suyitno, 1987). Semakin tinggi persentase deformasi berarti pergeseran bahan ketika ditekan semakin besar atau bahan semakin liat. Tabel 3 menunjukkan nilai deformasi bakso tidak berbeda nyata. Nilai deformasi antara 44,79 $\pm 3,93 \%-47,79 \pm 1,81 \%$. Faktor yang mempengaruhi deformasi adalah daging dan tapioka yang ditambahkan. Pada penelitian ini, jumlah daging dan tapioka yang ditambahkan untuk setiap formula adalah sama. Oleh sebab itu persentase deformasi bakso dengan penambahan lidah buaya tidak berbeda nyata.

\section{Tingkat Kesukaan Bakso dengan Penambahan Gel Lidah Buaya}

Hasil pengujian tingkat kesukaan terhadap aroma, warna, tekstur, rasa dan kesukaan keseluruhan terhadap bakso dengan penambahan gel lidah buaya dapat dilihat pada Tabel 4. Hasil uji kesukaan terhadap bakso menunjukkan bahwa aroma dan rasa serta kesukaan keseluruhan bakso tidak berbeda nyata. Skor nilai yang diperoleh adalah 3,0-3,5 yang berarti bakso disukai oleh panelis. Faktor yang menentukan aroma maupun rasa adalah daging dan bumbu- bumbu yang ditambahkan. Pada penelitian ini daging dan bumbu yang ditambahkan sama, sedangkan lidah buaya yangditambahkan komponen utamanya adalah air. Oleh sebab itu, tidak memberikan perbedaan pada aroma maupun rasa yang nyata pada bakso.

Warna bakso ditentukan oleh daging ayam ras yang digunakan. Warna daging ayam kemerahan karena kandungan pigmen mioglobin. Pemasakan mengakibatkan warna daging ayam menjadi pucat dan agak kehijauan setelah dimasak (Pizato dkk., 2015). Hasil pengujian menunjukkan sedikit perubahan warna pada bakso ayam, namun masih dalam kategori disukai. Hal ini disebabkan oleh penambahan gel lidah buaya hanya sedikit dan warna gel bening kehijauan hanya mengakibatkan sedikit perubahan kesukaan

Kesukaan terhadap kekenyalan bakso menunjukkan perbedaan yang nyata, namun masih dalam kategori disukai (nilai 3,20-3,95). Semakin banyak penambahan gel lidah buaya, kekenyalan semakin disukai. Sesuai hasil pengujian secara obyektif (Tabel 4) penambahan gel lidah buaya mengakibatkan kekenyalan semakin rendah dan semakin lunak. Bakso tanpa gel lidah buaya teksturnya paling keras dan kenyal ternyata kurang disukai. Hal ini berarti, penambahan gel lidah buaya dapat meningkatkan kesukaan terhadap tekstur bakso.

\section{KESIMPULAN}

Penambahan gel lidah buaya pada pembuatan bakso dapat menurunkan oksidasi lemak bakso. Substitusi gel lidah buaya pada rasio air/gel lidah buaya 55/45- 40/60 mampu menurunkan angka asam, angka peroksida dan angka TBA. Tekstur bakso dengan penambahan gel lidah buaya lebih lunak dan kekenyalan berkurang dan disukai. Secara keseluruhan, tingkat kesukaan bakso tidak berbeda nyata. Bakso dengan akseptabilitas dan aktivitas antioksidasi tinggi adalah yang dibuat dengan penambahan gel lidah buaya dengan rasio air/gel lidah buaya 55/45-40/60.

\section{UCAPAN TERIMA KASIH}

Penulis mengucapkan terima kasih kepada Universitas Mercu Buana Yogyakarta melalui LPPM, atas bantuan dana yang diberikan melalui Surat Tugas Pelaksanaan Penelitian Nomor 50/LPPM/UMBY/III/2017, Tanggal 20 Maret 2017.

\section{DAFTAR PUSTAKA}

Adawiyah, D. R., Soekarto, T.S., \& Hariyadi, P. (2012). Fat hydrolysis in a food model system: Effect of water activity and glass transition. International Food Research Journal, 19(2): 737-741.

Ammar, A. S. M., El-Hady, E.-S. A. A., \& El-Razik, M. M. A. (2014). Quality characteristics of low fat meat balls as affected by date seed powder, wheat germ and pumpkin flour addition. Pakistan Journal of Food Sciences, 24(4s): 175-185.

Anonim. (1995). Standar Nasional Indonesia Bakso Daging. Jakarta: Dewan Standarisasi Nasional.

AOAC. (1970). Official Methods of Analysis of AOAC International (11 $1^{\text {th }}$ ed.). AOAC Washington, D.C., 392-398.

Apriyantono, A., Fardiaz, D., Puspitasari, N., Sedarnawati, \& Budiyanto, S. (1989). Analisis Pangan. PAU Pangan dan 
Gizi, IPB, 96-104.

Bostami ABM, R., Seok Mun, H., \& Yang, C. J. (2017). Breast and Thigh Meat Chemical Composition and Fatty Acid Profile in Broilers Fed Diet with Dietary Fat Sources. Journal of Food Processing \& Technology, https://doi.org/10.4172/2157-7110.1000672.

Can, O.P, \& Harun, F.I. (2015). Shelf Life of Chicken Meat Balls Submitted to Sous Vide Treatment. Brazilian Journal of Poultry Science Revista Brasileira, 17(2): 137-144. https://doi.org/10.1590/1516-635x1702137-144.

Cheng, J.H. (2016). Lipid Oxidation in Meat. Journal of Nutrition \& Food Sciences, 6(3): 12-14. https://doi.org/10.4172/2155-9600.1000494.

Chung, T.H., \& Choi, I.H. (2016). Growth Performance and Fatty Acid Profiles of Broilers Given Diets Supplemented with Fermented Red Ginseng Marc Powder Combined with Red Koji. Brazilian Journal of Poultry Science, 18(4):733-738.

Gacula, M. C., \& Singh, J. (1984). Statistical Methods in Food and Consumer Research.Orlando. San Diego. New York. London: Academic Press, Inc.

Horax, R., Hettiarachchy, N., \& Islam, S. (2005). Total Phenolic Contents and Phenolic Acid Constituents in 4 Varieties of Bitter Melons (Momordica charantia) and Antioxidant Activities of their Extracts. Journal of Food Science, 70(4): C275-C280. 2621.2005.tb07173.x.

Hu, Y., Xu, J., \& Hu, Q. (2003). Evaluation of Antioxidant Potential of Aloe vera (Aloe barbadensis Miller) Extracts. Journal of Agricultural and Food Chemistry, 51(26): 77887791. https://doi.org/10.1021/jf034255i.

Huff-Lonergan, E., \& Lonergan, S. M. (2005). Mechanisms of water-holding capacity of meat: The role of postmortem biochemical and structural changes. Meat Science, 71(1): 194-204. https://doi.org/10.1016/j.meatsci.2005.04.022.

Kramer, A. A., \& Twigg, B.A. (1966). Fundamentals of Quality Control for the Food Industry. Fundamental of Quality Control for the Food Industry. (2 ${ }^{\text {nd }}$ ed.). Westport. Connecticut: The AVI Publishing Company, Inc.

Luckose, F., \& Pandey, M. C. (2014). Combined Effect of Non Meat Proteins and Different Binders on Low Salt Poultry Meat Systems. International Journal of Advanced Research, 2(11): 413-424. http://www.journalijar.com/uploads/188_IJAR4394.pdf.

Melia, S., Juliyarsi, I., \& Rosya, A. (2010). Peningkatan Kualitas Bakso Ayam dengan Penambahan Tepung Talas sebagai Subtitusi Tepung Tapioka. Jurnal Petemakan, 7(2) : 62-69. https://www. google.co.id/?gws_rd=cr\&ei= hS54WOLGCYmBvQSes]XYBQ\#q=pengolahan+bakso+aya $\mathrm{m} \% 2 \mathrm{C}+\mathrm{pdf}+\% 2 \mathrm{C}+$ jurnal.

Montolalu, S.N., Lontaan, S., Sakul, A., \& Mirah, D.P. (2013). Sifat Fisiko-Kimia dan Mutu Organoleptik Bakso Broiler Dengan Menggunakan Tepung Ubi Jalar (Ipomoea batatas L.). Jurnal Zootek ("Zootek"Journal), 32(5):1-13.

Munoz, O.M., Leal, X., Quitral, V., \& Cardemil, L. (2015). Extraction, Characterization and Properties of the Gel of Aloe Vera (Aloe barbadensis Miller) Cultivated in Chile. Medicinal \& Aromatic Plants, 4(3): 1-7. https://doi.org/10.4172/21670412.1000199.

Nuryati, L., Noviati, Waryanto, B., \& Widaningsih, R. (2015). Outlook Komuditas Pertanian Sub Sektor Peternakan: Daging Ayam. Pusat Data dan Sistem Informasi Pertanian Sekretariat Jenderal Kementerian Pertanian.

Pizato, S., Cortez-Vega, W. R., \& Prentice, S. (2015). Quality assessment of cooked chicken breast meat at different storage temperatures. International Food Research Journal,
22(1): 143-154.

Riyanto, \& Wariyah,Ch. (2012). Stabilitas sifat antioksidatif lidah buaya (Aloe vera var.chinensis) selama pengolahan minuman lidah buaya. Agritech, 32(1): 73-78. http://jurnal.ugm.ac.id/agritech/article/view/9659/7234.

Scala, K. D., Vega-Gálvez, A., Ah-Hen, K., Nuñez-Mancilla, Y., Tabilo-Munizaga, G., Pérez-Won, M., \& Giovagnoli, C. (2013). Chemical and physical properties of aloe vera (Aloe barbadensis Miller) gel stored after high hydrostatic pressure processing. Food Science and Technology (Campinas), 33(1): 52-59. https://doi.org/10.1590/S010120612013005000002.

Sultana, B., \& Anwar, F. (2008). Flavonols (kaempeferol, quercetin, myricetin) contents of selected fruits, vegetables and medicinal plants. Food Chemistry, 108(3): 879-884.

Suyitno. (1987). Petunjuk Laboratorium Pengujian Sifat Fisik Bahan Pangan. PAU Pangan dan Gizi, UGM, Yogyakarta.

Swarno, G., Rosyidi, D., \& Thohari, I. (2015). Kualitas Fisik (pH, WHC, Susut Masak, Tekstur) dan Organoleptik Bakso Daging Kalkun. Fakultas Peternakan, Universitas Brawijaya, Malang. http://fapet.ub.ac.id/wpcontent/uploads/2015/04/KUALITAS-FISIK-pHWHCSUSUT-MASAK-TEKSTUR-DAN-ORGANOLEP.

Tako, M., Tamaki, Y., Teruya, T., \& Takeda, Y. (2014). The Principles of Starch Gelatinization and Retrogradation. Food and Nutrition Sciences, 5(3): 280-291. https://file.scirp.org/pdf/FNS_2014012210240970.pdf.

Tao, L. (2015). Oxidation of Polyunsaturated Fatty Acids and its Impact on Food Quality and Human Health. Advances in Food Technology and Nutritional Sciences, 1(6): 135-142. https://doi.org/10.17140/AFTN-SOJ-1-123.

Wariyah, Ch., \& Riyanto. (2016). Antioxidative Activity of Microencapsulated Aloe vera (Aloe vera var. Chinensis) Powder with Various Concentrations of Added Maltodextrin. International Food Research Journal, 2:537542.

http://www.ifrj.upm.edu.my/23\%20(02)\%202016/(12).pd f.

Winang, T. (2015). Penggunaan Sodium Tripolifosfat sebagai Pengental pada Proses Pembuatan Bakso Di Beberapa Pasar di Kabupaten Sleman DIY. Skripsi. Fakultas Agroindustri. Argos Press.

Yen, G. C., \& Duh, P. D. (1994). Scavenging Effect of Methanolic Extracts of Peanut Hulls on Free-Radical and Active-Oxygen Species. Journal of Agricultural and Food Chemistry, $42(3)$ :629-632. https://doi.org/10.1021/jf00039a005. 